\title{
THE L'ENFANT PLAN AND THE BOTANIC GARDEN
}

\author{
BY HARLEAN JAMES \\ Secretary, American Civic Association
}

A new Botanic Garden extending over hundreds of acres, with opportunity for rich varieties of vegetation and scientific experiment, instead of the present small plot obstructing the development of the

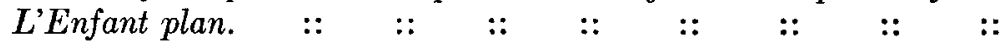

$\mathbf{I}$

IN every department of public affairs there comes, sooner or later, the clash between the interests of the many and the advantage of the few, the conflict between the vision of future greatness and the blindness of temporary expediency. The proposed removal of the Botanic Garden to the Mount Hamilton site and the development of the mall around the new Grant Memorial in accordance with the plan of 1901 now brings a clear-cut issue with the attempt to enlarge the Botanic Garden in its present site.

The Botanic Garden lies across the street from the Capitol on the south side of Pennsylvania Avenue and overlaps the plan to develop the mall from the Capitol to the Lincoln Memorial, a plan which conforms to the L'Enfant plan as adapted by the plan of 1901 . In selecting the sites for the Grant and Lincoln Memorials congress has respected the design for the mall. The Botanic Garden, which covers some twelve acres including the sites of the Grant and Meade Memorials and the Bartholdi fountain, is enclosed by a low brick wall surmounted by a high iron fence. The massive Grant Memorial, which is now nearing completion, stands just inside the fence directly across from the Capitol grounds.

In the sundry civil bill for 1921-22 an appropriation of $\$ 5,000$ was made by congress for the unveiling and dedication of the memorial to General Grant, and "for removal of so much of the iron part of the brick and iron fence on the east side of the Botanic Garden as in the opinion of the superintendent of the garden may be necessary to improve the surroundings of said memorial." It is perfectly clear that the Grant Memorial already placed in relation to the parked approach from the mall and the Meade Memorial which will be erected in the northwest corner of the garden are the beginnings of the development of the mall in accordance with the plans of the Fine Arts Commission. This development and the Botanic Garden cannot occupy at one and the same time the same space. There is only one answer. The Botanic Garden must go.

This does not mean that the Botanic Garden should be abolished. Far from it. At the request of the committee on the library of the house of representatives, a plan has been prepared by the Fine Arts Commission which would give Washington a national Botanic Garden extending over hundreds of acres and affording opportunity for scientific experiment and landscape development comparable with the most famous botanic gardens in other countries. For this national 
Botanic Garden the commission has recommended a site bordering the Anacostia River which, according to the experts of the agricultural department, would meet the requirements for such a garden. The suggestion is further made that the flower beds and greenhouses in present gardens be removed to some site convenient to the Capital, where they may serve their present purpose and not interfere with the development of the L'Enfant plan.

II

The proposed removal of the Botanic Garden to a suitable site and the development of the mall recalls the origin and purpose of the Fine Arts Commission, which was created by congress in 1910 to carry out the plan of 1901 and to insure artistic merit and architectural unity in governmental art. The plan of 1901, drawn up by the senate commission, composed of Daniel Burnham, Charles McKim, Augustus St. Gaudens and Frederick Law Olmsted, was a restatement and enlargement of the L'Enfant plan of 1792 , to which Washington owes its distinction, but which had been forgotten and ignored for many years. It was more than fitting that on the one hundredth anniversary of the removal of the seat of government to the District of Columbia the vision of Washington and Jefferson should be recognized and their plan revived and vivified.

The present Commission of Fine Arts is composed of Charles Moore, John Russell Pope, James L. Greenleaf, James E. Fraser, Henry Bacon, Louis Ayres, H. Siddons Macobrey, with Colonel C. O. Sherrill as secretary and executive officer. The Commission surveying the whole field has been enabled to select a site appropriate for the Botanic Garden and one which will supplement and harmonize with other developments. For some years the War Department, acting through the Anacostia Reclamation Board, has been reclaiming the Anacostia flats. The commission proposes that the Botanic Garden be located on 433 acres included in the Anacostia reclamation project, and 367 acres to be purchased at a cost less than the saving in dredging which would otherwise be undertaken by the reclamation board. The board has endorsed the plan of the Fine Arts Commission, and Senator Brandegee has re-introduced into the 67th congress a bill (Senate 4485) to authorize the extension of the taking line of the Anacostia project as defined in the act of 1914, amended in 1917, to include the 367 acres designated by the Fine Arts Commission.

The combined site contains thirtytwo varieties of soil and includes elevations which vary from sea level to 239 feet. Many plants and trees are already growing on Mount Hamilton and vicinity. In the present enclosed gardens the variation in soil and altitude is so slight and the area so restricted that a true botanic garden could never be developed even if the land were not already dedicated to the truly imposing approach to the Capitol planned by the Fine Arts Commission.

The Mount Hamilton Botanic Gardens would be reached by a two-mile drive on Maryland Avenue, a wide, parked thoroughfare which is completed about two-thirds of the distance. The gardens would lie along the main highway from Baltimore to Washington; the Pennsylvania Railroad would cross the north end, and the Baltimore and Annapolis electric line would traverse the south end. Thus the electric, rail and motor approach to the Capitol from the northeast would be relieved from the ragged and unkempt appearance which the straggling outskirts now 
present to the traveler. The river would make possible water gardens of rare beauty. On the lowlands eighty acres in wild rice would afford a bird sanctury. The waters of the river would be diverted into lakes and moats. The wonderful Shaw lily-pond would be preserved and made to rival those of the tropics. Wooded billtops, sunny slopes and shaded nooks would provide for shrubs and trees of many varieties.

The Brandegee bill has been referred to the committee on library, of which Senator Brandegee is chairman. The other members of the committee are Senators Wadsworth of New York, Knox of Pennsylvania, McCumber of North Dakota, Williams of Mississippi, McKellar of Tennessee and Broussard of Louisiana.

\section{III}

Seeking to compromise in a case where compromise means fatal delay, Representative Langley has introduced a bill into the house (H. R. 2166) which would enlarge and entrench the present Botanic Garden, by adding two parcels of land known as East and West Seaton Park. It is true that the bill would prohibit the erection of "conservatories and other improvements of a permanent character . . . to areas not intended as sites for future public buildings and drive- ways in the plan for that vicinity prepared by the Park Commission." It is obvious that no more buildings of any sort, permanent or temporary, should be erected on any of the land included in the mall, except in strict accordance with the entire landscape plan of the Fine Arts Commission. Nothing could be more short-sighted than to enlarge the present Botanic Garden. The Langley bill was referred to the committee on library, composed of Representatives Norman J. Gould of New York, Fess of Ohio, Luce of Massachusetts, Park of Georgia and Gilbert of Kentucky.

The people of the country have faith in the vision and ability of the Commission of Fine Arts, and, when they know of the conflict between the vision of the commission and the vested interests in things as they are, they will lose no time in letting the senate and house committees on library know their views. Every city planner, every landscape architect, every architect, every civic-leader may perform a public service by communicating with the congressional committees urging an early favorable report on the Brandegee bill, which is the first step to secure for Washington worthy botanic gardens and the proper development of the mall approach to the Capitol planned so many years ago. 